\title{
Ulysses Prentiss Hedrick (18704951)
}

\author{
Roger D. Way \\ Cornell University, New York State Agricultural Experiment Station, Geneva, NY 14456
}

Ulysses P. Hedrick, renowned fruit breeder and skillful administrator of horticultural research, was born in 1870 on a farm in Independence, Iowa. His restless parents moved the family to Little Traverse, Mich., where they cleared beech and maplewoodland to establish another farm. As a youth, Hedrick's love of nature motivated him to attempt to understand its mysteries.

He graduated in 1893 from Michigan State College, where he served as assistant horticulturist for 2 years. He subsequently was appointed professor of horticulture at the Oregon Agricultural College (1895-97), Utah Agricultural College (1897-99), and Michigan State College (1899-1905). In 1905 he joined the New York State Agricultural Experiment Station, Geneva, where for the next 33 years he conducted research in pomology and served on the faculty, first as head of horticultural research, then as vice director (1921-28), and finally director (1928-38).

One of Hedrick's greatest talents was as an administrator of agricultural research. He was the sixth director of the station and the first local staff member to be appointed to that position. As director, Hedrick transferred the departments of agronomy and poultry husbandry to the Ithaca campus of Cornell Univ.; expanded the horticultural research program to include vegetable crops, entomology, plant pathology, seed investigations, and food science; and created new departments. These accomplishments are especially impressive since they occurred through the Great Depression. During his tenure, the station became one of the world's leading fruit-breeding institutions. His "drive, inspiration, and leadership were vital to the work of the station" (Gates, 1966).

Hedrick was politically astute. He was personally acquainted with New York governor Franklin D. Roosevelt and had considerable influence with the state legislature, which appropriated the station's operating funds. In 1930 he lobbied the legislature and received funds to build and equip a new horticulture building. During the same period, he requested

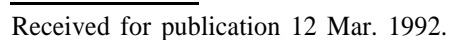

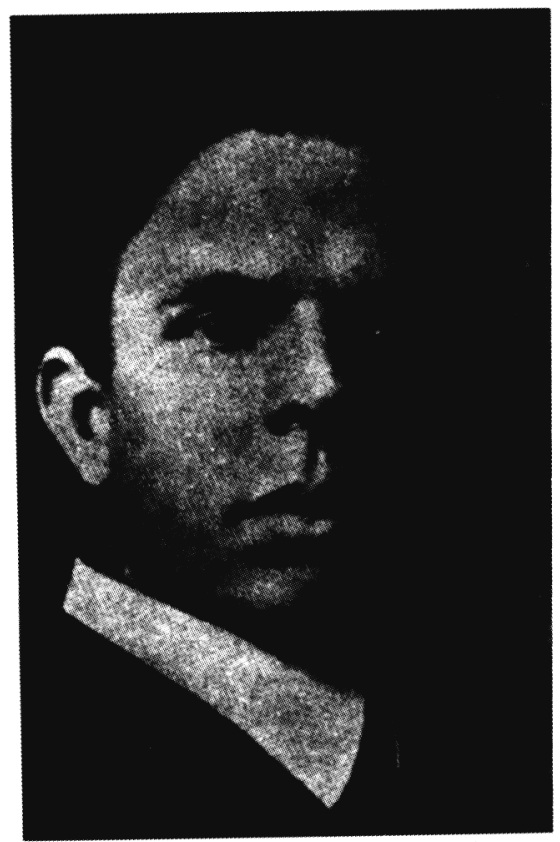

and received state grants to finance experimental greenhouses; research projects on the corn borer, grapes and other small fruits, and fruit and vegetable by-products; seed investigations; and legume inoculations.

In 1923 the station became part of Cornell Univ., making Hedrick subordinate to Cornell's dean of the College of Agriculture. Hedrick was unaccustomed to being subordinate to anyone and Dean Ladd had difficulty managing him. Hedrick usually manipulated the grant writing to benefit his own station's needs.

Hedrick's talent as a writer rivaled his talents as an administrator. He published 88 bulletins, articles, circulars, and notes, and 17 horticultural books, including six in his "Fruits of New York" series (1908-25), still a standard reference for scholars studying the origins and descriptions of fruit cultivars. He was also a historian, publishing a well-known book on the history of agriculture and another on the history of horticulture.

Hedrick was an excellent pornological researcher. According to Gates (1966), "it was not pure science as studied only in the laboratory, devoid of any hope of practical applica- tion, that interested Hedrick. Instead, his concern was to investigate the farmer's problems, in the hope of providing solutions and improvements that would increase output and lessen labor." Between 1905 and 1928, he and his staff bred and introduced 81 fruit cultivars: 31 apples, including the commercially important 'Cortland', 'Kendall', 'Early McIntosh', 'Lodi', 'Macoun', and 'Milton'; five pear cultivars, including 'Gorham'; three plums, including 'Stanley'; one cherry; one nectarine; 14 grapes, including 'Fredonia' and 'Ontario'; one gooseberry; 11 raspberries, including 'Newburgh'; and 14 strawberries.

Numerous organizations, scientific and otherwise, gained immensely from Hedrick's membership. He served as President of ASHS in 1913, the New York State Agricultural Society, and the New York State Horticultural Association (NYSHA), an organization he founded. He received numerous awards for his accomplishments, including fellowship in the American Association for the Advancement of Science, the Horticultural Society of Germany, and NYSHA. He received the Wilder Medal from the American Pornological Society, the Robert White Medal from the Massachusetts Horticultural Society, and several honorary degrees.

Hedrick died in 1951 at Clifton Springs, N.Y., at the age of 80 . He is remembered as a gentle man, loved and admired by those who worked with him.

\section{References}

American Pomological Society. 1983. American Pomological Society U.P. Hedrick awards. Fruit Var. J. 37(2): 59

Chapman, P.J. The first one hundred years of the New YorkState Agricultural Experiment Station at Geneva, N.Y. (unpublished).

Encyclopedia Britannica. 1963. Hedrick, Ulysses Prentiss. Encyclopedia Britannica 11:378.

Gates, P.W. 1966. Ulysses Prentiss Hedrick, horticulturist and historian. New York History 47(3):219-247.

Lamb, R.C. 1983. New American Pomological Society Award honors U.P. Hedrick. Fruit Var. J. 37(4):8687.

Luckett, J.D. 1951. Ulysses Prentiss Hedrick. Station News, New York State Agr. Expt. Sta., Geneva. 15 Nov. 1951. 